\title{
ANALISIS PERDAGANGAN INDONESIA PASCA PEMBERLAKUAN ACFTA (STUDI KOMPARATIF INDONESIA-CHINA)
}

\author{
Oleh: \\ Muslikhati \\ Mahasiswa Magister Ilmu Ekonomi Universitas Brawijaya Malang \\ E-mail/No. Hp: Mulikhati03@yahoo.com/081334411335 \\ David Kaluge \\ Fakultas Ekonomi Universitas Brawijaya Malang \\ E-mail/No. Hp: dkaluge@yahoo.com/ -
}

\begin{abstract}
Every international economy linking countries through two channels: trade in goods and services (real sector) and financial sector. Trade relations means that some products from a country that exported abroad, while some goods that are consumed or invested in the country are imported from abroad. The strong role of international trade is partly reflected in the goods market will be able to help us to know how big contribution to the real sector is affected by exchange rate and net exports to increase income or national output. All economies, regardless of size, depends on other economies and are affected by events beyond its limits.The existence of an agreement between Indonesia and China as stipulated in the agreement more or less ACFTA will influence the increase or decrease in Indonesia's trade balance are reflected in an increase or decrease in GNP. Indonesia's ability to see its comparative advantage will be able to increase the competitiveness of Indonesian products in the international market.
\end{abstract}

Keywords: international trade, net export, and gross domestic product

\section{PENDAHULUAN}

Permulaan abad dua puluh menjadi awal dimulainya hubungan perdagangan international. Perekonomian nasional menjadi saling berhungan, hubungan ini sering disebut dengan istilah globalisasi yaitu pergerakan ke suatu perekonomian global, (Dornbusch.2004). Efek perekonomian luar negeri dengan adanya perdagangan internasional akan berpengaruh terhadap perekonomian domestic. Setiap perekonomian internasional menghubungkan Negaranegara melalui dua jalur: perdagangan barang dan jasa (sector riil) dan sector keuangan. Hubungan perdagangan berarti adanya beberapa produk dari suatu Negara yang diekspor ke luar negeri, sementara beberapa barang yang dikonsumsi atau diinvestasi di dalam negeri diimpor dari luar negeri.

Disetiap Negara di dunia pertumbuhan ekonomi senantiasa dijadikan sebagai focus dari setiap pembahasan, karena pertumbuhan ekonomi selalu menjadi factor penting dalam keberhasilan perekonomian suatu Negara dalam jangka panjang. Untuk dapat meningkatkan pertumbuhan ekonomi maka mutlak bagi suatu Negara untuk membuka perekonomiannya dengan melakukan perdagangan dengan 
berbagai Negara atau dalam konteks perekonomian adalah melakukan perdagangan internasional.

Pada tanggal 4 Nopember 2010, pemerintah Republik Indonesia bersama Negara ASEAN menandatangani framework Agreement on Comprehensive Economic Co-operation between the Association of South East Asian Nations and the People's Republic of China. Melalui perjanjian ASEANChina Free Trade Area (ACFTA) ini, maka ASEAN mulai melakukan pasar bebas di kawasan ASEAN-China. Dan khusus di Negara-negara ASEAN-6 (Indonesia, Singapura, Thailand, Malaysia, Filipina ,dan Brunei) telah menerapkan bea masuk $0 \%$ per januari 2004 untuk beberapa produk berkategori Early Harvest Package.

Sedangkan mulai diberlakukannya bea masuk $0 \%$ untuk semua produk adalah ditetapkan sejak 1 Januari 2010. Dari penetapan ini maka Indonesia bagaimanapun kondisi perekonomiannya harus bersaing di pasar global. Kemampuan Indonesia dalam memproduksi output yang dapat diterima di pasar global menjadi hal yang tidak bisa ditewar lagi, mengingat kenaikan pertumbuhan ekonomi ditentukan secara signifikan melalui peningkatan net ekspornya. Untuk memacu peningkatan pertumbuhan ekonomi, untuk itu pemerintah Indonesia harus memperhatikan pertumbuhan sector riil secara terarah, terprogram dan berkelanjutan.

Sebagai acuan Purnomo dan Aliman (2001), membahas tentang hubungan ekspor terhadap pertumbuhan ekonomi (studi kasus 1969-1997). Berdasarkan hasil penelitian menyimpulkan bahwa adanya pola kausalitas dalam jangka pendek antara tingkat pendapatan nasional riil dengan tingkat ekspor riil, yaitu ditandai dengan signifikannya nilai koefisien $\mathrm{DLXR}_{t}$ (tingkat ekspor riil) dan nilai koefisien DLYR $_{\mathrm{t}}$ (tingkat pendapatan nasional riil). Dengan menggunakan uji kausalitas model koreksi kesalahan, didapat bahwa tingkat pendapatan nasional riil dalam mempengaruhi tingkat ekspor riil membutuhkan waktu relatif cepat. Apabila tingkat ekspor total riil Indonesia meningkat maka tingkat pendapatan nasional riil Indonesia juga akan meningkat .

Hasil studi empiris dengan menggunakan Uji Kausalitas model koreksi kesalahan menunjukkan adanya pola kausalitas timbal balik (tingkat ekspor riil mempengaruhi tingkat pendapatan nasional riil dan sebaliknya tingkat pendapatan nasional riil mempengaruhi tingkat ekspor riil). Dengan demikian studi empiris ini mendukung hipotesis bahwa pertumbuhan ekonomi dalam negeri mendukung ekspor.

Latif Adam (2003) melakukan studi tentang ACFTA dalam Perspektif Hubungan dagang Indonesia China. Menurut Adam 2 (dua) perspektif dalam hubungan dagang antara Indonesi-China yaitu : pola perdagangan dan struktur perdagangan.

Sinyal bahwa ACFTA berpotensi mengganggu eksistensi perekonomian nasional cukup jelas terlihat apabila kita mencermati pola perdagangan IndonesiaChina. Berbagai indikator mengenai pola perdagangan diantara kedua negara menunjukkan bahwa produk Indonesia semakin lama semakin inferior terhadap produk China. Secara eksplisit, hal ini terindikasi cukup jelas dari perkembangan ekspor dan impor

Pada periode 1990-2009, pertumbuhan ekspor Indonesia ke China (7,9\% per tahun) jauh lebih rendah dibandingkan dengan pertumbuhan impor Indonesia dari China $(17,1$ per tahun\%). Ini menunjukkan bahwa kemampuan penetrasi produk China ke 
pasar Indonesia relatif lebih tinggi dibandingkan kemampuan penetrasi produk Indonesia ke pasar China. Dalam konteks ini, pemberlakuan ACFTA dikhawatirkan akan mendorong peningkatan penetrasi produk China ke pasar Indonesia.

Kemungkinan

bahwa

pemberlakuan ACFTA akan mendorong semakin tingginya tingkat penetrasi produk China ke pasar Indonesia sangat tinggi. Argumentasinya, melalui ACFTA hambatan perdagangan diantara kedua negara akan semakin berkurang. Ini berarti bahwa kunci persaingan akan lebih banyak ditentukan oleh kemampuan daya saing. Masalahnya, berbagai studi menunjukkan bahwa beberapa elemen pembentuk daya saing, seperti tingkat efisiensi, produktivitas, dan lingkungan bisnis di China relatif lebih baik dibandingkan dengan di Indonesia.

Selain polanya yang semakin tidak menguntungkan, Indonesia juga menghadapi permasalahan struktural didalam menjalin hubungan dagang dengan China. Terdapat indikasi bahwa struktur perdagangan Indonesia dengan China bersifat asimetris. Artinya, di satu sisi, struktur ekspor Indonesia ke China masih sangat didominasi oleh produk primer, seperti minyak dan gas, hasil pertanian, dan pertambangan. Lebih dari itu, terdapat kecenderungan bahwa produk primer didalam struktur ekspor ke China, bukannya melemah, tetapi justru mengalami peningkatan Di sisi lain, struktur impor Indonesia dari China lebih banyak didominasi oleh produk industri pengolahan dengan proporsi yang cenderung terus meningkat.

Aryo Perbongso, CTD (2009) melakukan studi tentang Ancaman ACFTA. Menurut Aryo dengan membandingkan neraca perdagangan
Indonesi-China dari tahun 1999-2007 Indonesi mengalami surplus perdagangan dengan China, baru pada tahun 2008 perdagangan Indonesia mengalami deficit terhadap China, seiring dengan pertumbuhan ekonomi China yang sangat signifikan. (lihat gambar 1)

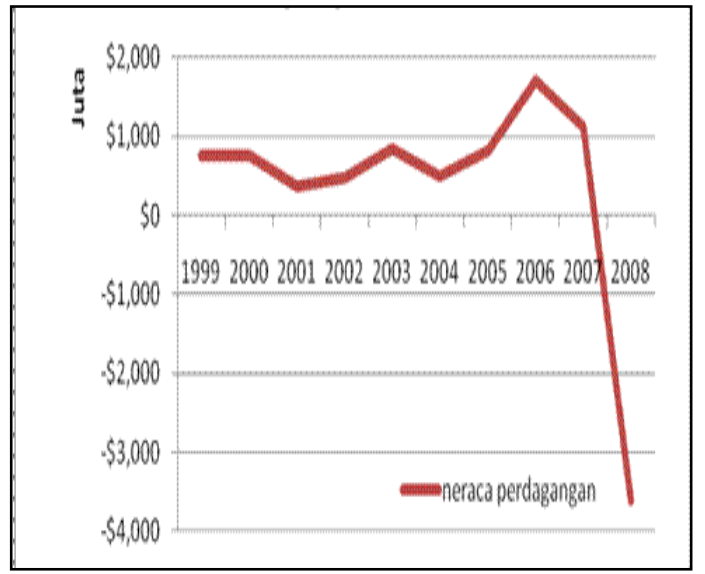

Gambar 1. Neraca Perdagangan Indonesia-China Sumber: UNCOMTRADE, diolah

Dengan diberlakukannya perjanjian ACFTA menurut Aryo akan menghasilkan kesempatan dan ancaman bagi industry-industri di Indonesia. Kesempatan bagi industri-industri di Indonesia yang memiliki comparative advantage terhadap China, dan begitu juga sebaliknya. Pada tahun 2008, Sektor-sektor Industri di Indonesia (berdasarkan SITC rev.3) yang memiliki comparative advantage terhadap China adalah barang-barang hasil alam selain makanan dan bahan bakar (SITC rev.3 kode 2), Bahan bakar mineral dan pelumas (SITC rev.3 kode 3), Minyak hewan dan tumbuhan (SITC rev.3 kode 4). 
Tabel 1. Neraca Perdagangan per komoditas tahun 2008 (US \$)

\begin{tabular}{crrr}
\hline $\begin{array}{c}\text { komoditas SITC } \\
\text { rev3 }\end{array}$ & Indonesia & \multicolumn{1}{c}{ China } & \multicolumn{1}{c}{$\begin{array}{c}\text { Neraca Perdagangan } \\
\text { per komoditas }\end{array}$} \\
\hline code 0 & 225.854 .311 & 672.885 .598 & 447.031 .287 \\
code 1 & 3.427 .315 & 94.763 .533 & 91.336 .218 \\
code 2 & 2.481 .450 .218 & 303.150 .885 & 2.178 .299 .333 \\
code 3 & 4.565 .777 .559 & 330.092 .644 & 4.235 .684 .915 \\
code 4 & 2.084 .943 .189 & 7.631 .457 & 2.077 .311 .732 \\
code 5 & 706.378 .727 & 1.988 .091 .231 & 1.281 .712 .504 \\
code 6 & 845.210 .042 & 3.795 .340 .338 & 2.950 .130 .296 \\
code 7 & 578.663 .550 & 7.124 .005 .007 & 6.545 .341 .457 \\
code 8 & 144.798 .810 & 933.210 .868 & 788.412 .058 \\
\hline
\end{tabular}

Sumber: UNCOMTRADE, diolah

Sedangkan sektor-sektor industri di China yang memiliki comparative advantage terhadap Indonesia adalah produk barang kimia ( SITC rev 3 kode 5), Barang Manufaktur berdasarkan material (SITC rev 3 kode 6), Mesin dan peralatan transportasi ( SITC rev 3 kode 7), Barang-barang manufaktur lainnya (SITC rev 3 kode 8 ).

Berdasarkan tabel diatas, dapat dilihat bahwa pada tahun 2008 total neraca perdagangan kita mengalami defisit sebesar \$3.612.667.840. Dengan diberlakukannya ACFTA (ASEANChina Free Trade Area) akan memberikan potensi defisit yang lebih besar terhadap neraca perdagangan antara Indonesia dengan China. Indonesia mungkin bisa berharap dari sektor pertambangan yang diwakilkan dalam SITC rev 3 dalam kode 2,3, dan 4 akan bertambah dengan diberlakukannya ACFTA.

Namun ancaman nyata terjadi dari sektor manufaktur karena dapat dilihat dari tabel diatas, neraca perdagangan antara Indonesia dengan China komoditas SITC rev.3 kode 5,6,7,8 mengalami defisit. Hal ini dapat mengakibatkan terancamnya sektor manufaktur Indonesia yang selama ini menjadi andalan menyerap tenaga kerja akibat diberlakukannya ACFTA.
Sedangkan untuk sektor SITC rev.3 code 0 dan 1, masih dilindungi oleh tarif karena termasuk dalam Highly Sensitive List (HSL). Berdasarkan Neraca Perdagangan keseluruhan pada tahun 2008, ACFTA lebih mengancam industri manufaktur di Indonesia dibandingkan China.

Berdasarkan uraian di atas, maka menarik untuk diteliti mengenai analisis kausalitas perdagangan antar kedua Negara yang direpresentasikan dari kenaikan Net Export terhadap Gross National Product. Bilamana terjadi suatu variable dapat menyebabkan pengaruh pada variable lain maka diperlukan kebijakan yang lebih nyata dari pemerintah untuk meningkatkan pertumbuhan ekonomi dengan mendorong sector riil.

\section{TINJAUAN PUSTAKA}

Perdagangan Internasional sebuah negara dapat ditunjukkan dengan nilai ekspor dan impor negara tersebur. Dalam teori, pengertian ekspor adalah suatu kegiatan yang menyangkut produksi barang dan jasa yang diproduksi di suatu negara tetapi untuk dikonsumsikan di luar batas negara tersebut (Boediono, 1984; 61-62). Orang yang melakukan kegiatan ekspor disebut eksportir. Dalam satu pengertian, 
importir adalah kebalikan dari eksportir; mereka menjual di dalam negeri dan membeli di pasar-pasar luar negeri. Meskipun demikian, hal-hal yang menjadi perhatian keduanya relatif sama.

Kegiatan produksi atau proses disini berbeda untuk masing-masing negara tergantung pada faktor yang dimiliki oleh negara tersebut. Suatu negara bisa memiliki lebih banyak atau lebih sedikit dari masing-masing faktor produksi dibandingkan dengan negaranegara lainnya. (Boediono, 1984; 61-62). Menurut teori Heckscher-Ohlin hal ini menunjukkan keunggulan komparatif dari masing-masing negara yang melakukan perdagangan internasional.

Secara sistematis dapatlah dikatakan bahwa ekspor merupakan sisa atau residu dari total produksi nasional $\left(\mathrm{Y}_{\mathrm{t}}\right)$ setelah dikurangi dengan kebutuhan total untuk konsumsi dalam negara $\left(\mathrm{C}_{\mathrm{d}}\right)$, (Bambang Triyaso, 1984; 221) atau:

$X_{t}=Y_{t}-C_{d t}$

Dimana: $\mathrm{t}=$ periode waktu

Dengan demikian ekspor (X) akan lebih tepat bila disebut sebagai sisa yang dapat diekspor atau eksportable surplus, model ini hanya berlaku bila:

$Y_{t}>C_{d t}$

Bila ketentuan-ketentuan diatas tidak dipenuhi, maka tidak ada lagi eksportable surplus. Persamaan identitas tersebut sebenarnya bersumber pada dasar pemikiran Keynes yang murni, (Triyaso, 1984; 212) yaitu:

$\mathrm{Y}=\mathrm{C}+\mathrm{I}+\mathrm{G}+\mathrm{X}-\mathrm{M}$

Dimana: $\mathrm{Y}=$ GDP $\quad$ (Produk Domestik Bruto); $\mathrm{C}=$ Konsumsi masyarakat; $\mathrm{I}=$ Total investasi masyarakat; $\mathrm{G}=$ Total konsumsi pemerintah; $\mathrm{X}=$ Ekspor; $\mathrm{M}=$ Impor
Pengertian dari eksportable surplus yaitu dimana ekspor merupakan sisa daripada total produksi nasional (Y) setelah dikurangi $(\mathrm{C}+\mathrm{I}+\mathrm{G})$. Adapun batasan yang harus dipenuhi dalam permasalahan ekspor yaitu:

$\mathrm{Y}>(\mathrm{C}+\mathrm{I}+\mathrm{G})$

Bila batas tersebut tidak dipenuhi maka eksportable surplus tidak akan ada lagi. Dapatlah dikatakan bahwa ekspor merupakan bagian perkembangan total produksi nasional di dalam negeri. Ekspor terjadi karena adanya perbedaan harga yang potensial dari pembelipembeli di luar negeri terhadap hargaharga yang terjadi di dalam negeri.

Model perekonomain yang meliputi kegiatan ekspor dan impor dinamakan perekonomian empat sektor atau perekonomian terbuka. Dalam model ini akan terlihat dua aliran baru dalam didalam sirkulasi aliran pendapatan, yaitu aliran pendapatan yang diterima dari ekspor, yang merupakan suntikan kepada aliran pendapatan, dan aliran pengeluaran untuk membeli barang yang diimpor, yang merupakan bocoran kepada aliran pendapatan. Kedua aliran ini akan mempengaruhi keseimbangan perekonomian negara. Ekspor akan meningkatkan pendapatan nasional pada keseimbangan dan menciptakan pertumbuhan ekonomi. Akan tetapi sebaliknya, impor menurunkan pendapatan nasional pada keseimbangan perekonomian negara. (Sukirno, 1997; 377).

Dalam perekonomian terbuka, sektor ekonomi dibedakan dalam empat golongan, yaitu perusahaan, rumah tangga, pemerintah, dan luar negeri. Penggunaan faktor-faktor produksi oleh sektor perusahaan akan mengakibatkan aliran pendapatan ke sektor rumah tangga, yang berupa gaji dan upah, sewa, 
bunga dan keuntungan. Sedangkan rumah tangga dan perekonomian akan menggunakan pendapatan mereka untuk transaksi: membeli barang-barang dan jasa-jasa yang diproduksi oleh sektor perusahaan dan pengeluaran konsumsi barang dan jasa yang diproduksi di dalam negeri, membayar pajak pendapatan kepada pemerintah, menngimpor yaitu membeli barangbarang yang diproduksi oleh negara lain, dan menabung sisa pendapatan yang diperoleh ke dalam lembaga keuangan.

Disamping adanya aliran uang untuk membayar impor, perekonomian terbuka menyebabkan pula aliran pengeluaran ke sektor perusahaan, yaitu aliran yang diakibatkan oleh pembayaran pada ekspor sektor perusahaan. Dari aliran pengeluaran berbagai sektor dalam perekonomian terbuka, komponen pengeluaran agregat terhadap GDP yaitu: 1. Pengeluaran konsumsi rumah tangga atas barang-barang konsumsi dan jasa-jasa yang diproduksikan di dalam negeri; 2. Investasi perusahaan, yaitu pengeluaran penanaman modal atas barang-barang modal yang diproduksikan di dalam negeri; 3 . Pengeluaran pemerintah, yaitu pengeluaran konsumsi dan investasi pemerintah; dan 4. Ekspor, yaitu pengeluaran negara-negara lain atas barang-barang dan jasa-jasa yang dihasilkan sektor perusahaan.

Dalam model basis ekspor, tidak diperhatikan tabungan dan pengeluaran untuk investasi didalam kerangka pengeluaran domestik, karena yang hendak dijelaskan bukan depresi dalam seluruh perekonomian tetapi perubahan pendapatan regional. Fungsi tabungan dalam menciptakan kebocoran dalam perekonomian dianggap dianggap sebagai impor, yang menerapkan fungsi pendapatan. Fungsi investasi sekarang sebagai ekspor, yang merupakan pendorong dari perekonomian yang berbasis ekspor.

Teori integrasi ekonomi mengacu pada suatu kebijakan komersial atau kebijakan perdagangan secara diskriminatif menurunkan atau menghapuskan hambatan-hambatan perdagangan hanya di antara negaranegara yang saling sepakat untuk membentuk suatu integrasi ekonomi terbatas. Tingkatan integrasi ekonomi itu sendiri bervariasi mulai dari pengaturan perdagangan preferensial, yang selanjutnya dapat dikembangkan menjadi pembentukan kawasan/area perdagangan bebas, kemudian menjadi persekutuan pabean, pasaran bersama dan pada akhirnya akan menjurus pada penyatuan ekonomi secara menyeluruh.

Pengaturan Perdagangan

Preferensial (preferencial trade arrangements) dibentuk oleh negaranegara yang sepakat menurunkan hambatan-hambatan perdagangan yang berlangsung di antara mereka, dan membedakannya dengan yang diberlakukan terhadap negara-negara luar yang bukan anggota. Contohnya adalah Skema Preferensi Persemakmuran Inggris (British Commonwealth Preference Scheme) yang dibentuk pada tahun oleh Kerajaan Inggris. Keanggotaannya meliputi wilayah-wilayah dibawah kekuasaannya dan sebagian bekas daerah koloni atau jajahannya.

Sedangkan Kawasan Perdagangan Bebas (free trade area) adalah bentuk integrasi ekonomi yang tinggi dimana semua hambatan perdagangan tarif maupun non-tarif di antara negaranegara anggota telah dihilangkan sepenuhnya, namun masing-masing negara anggota tersebut masih berhak untuk menentukan sendiri apakah mereka hendak mempertahankan atau menghilangkan hambatan-hambatan perdagangan yang diterapkannya 
terhadap negara-negara luar yang bukan anggota. Contohnya adalah Assosiasi Perdagangan Bebas Eropa (EFTA, European Free Trade Association) yang didirikan tahun 1960 oleh Inggris, Austria, Denmark, Norwegia, Portugal, Swediadan Swiss. Dan Perjanjian Perdagangan Bebas Amerika Utara (NAFTA, North American Free Trade Agreement), yang dibentuk oleh Amerika Serikat, Kanada, dan Meksiko pada tahun 1993.

Kemudian, persekutuan pabean (customs union), mewajibkan semua negara anggota untuk tidak hanya menghilangkan semua bentuk perdagangan di antara mereka namun juga menyeragamkan kebijakan perdagangan mereka terhadap negaranegara luar yang bukan anggota. Contohnya adalah Uni Eropa (EU, European Union) atau yang semula lebih dikenal sebagai Pasaran Bersama Eropa (European Common Market) yang dibentuk tahun 1957 oleh Jerman Barat, Prancis, Italia, Belgia, Belanda dan Luxemburg.

Pada tahap berikutnya, integrasi ekonomi tersebut menjelma menjadi pasaran bersama (common market). Pada bentuk integrasi ekonomi ini, bukan hanya perdagangan barang saja yang dibebaskan, namun juga arus-arus faktor produksi seperti tenaga kerja dan modal. Pada tingkatan tertinggi dari integrasi ekonomi, yakni uni ekonomi (economic union), harmonisasi atau penyelarasan itu dilakukan lebih jauh, bahkan dengan menyeragamkan kebijakan-kebijakan moneter dan fiskal dari masing-masing negara anggota.Contoh uni ekonomi ini adalah Benelux, yang merupakan uni ekonomi Belgia, Belanda dan Luxemburg. Selain itu contoh uni ekonomi dan moneter yang benar-benar menyeluruh adalah Amerika Serikat.

\section{METODE PENELITIAN}

Penelitian ini melakukan analisis perdagangan Indonesia China dengan pendekatan uji kausalitas, peneliti melakukan studi empiris dengan sampel penelitian 2 (dua) Negara (Indonesia dan China) pada tahun 1980 - 2009. Data yang digunakan peneliti dalam analisis ini adalah data sekunder yang diperoleh dari World Trade Organization (WTO). Variable-variabel yang diteliti adalah variable Net ekspor dan GDP di masingmasing negara. Dalam penelitian ini tidak ada variable terikat, karena kedua variable merupakan variable independen yang saling mempengaruhi. Alat analisis yang digunakan dalam penelitian ini menggunakan uji kausalitas Granger (1969). Yaitu metode analisis dengan mengestimasi arah hubungan sebab akibat di antara variabel-variabel ekonomi yang diestimasi.

$$
\begin{gathered}
Y=\alpha_{0}+\alpha_{1} X+\alpha_{2} \mathrm{X}_{(-1)}+\alpha_{3} \mathrm{X}_{(-2)}+ \\
\beta_{1} \mathrm{Y}_{(-1)}+\beta_{2} \mathrm{Y}_{(-2)}+\mathrm{U}_{1} \ldots \ldots \ldots \ldots \ldots . .(1)
\end{gathered}
$$

$\mathrm{Y}=\alpha_{0}+\beta_{1} \mathrm{Y}_{(-1)}+\beta_{2} \mathrm{Y}_{(-2)}+\mathrm{U}_{2}$

$$
\text { Null hypothesis }\left(\mathrm{H}_{0}\right): \alpha_{1}=\alpha_{2}=0
$$

Y menyebabkan $\mathrm{X}$ jika $\mathrm{H}_{0:} \alpha_{1}=\alpha_{2}=0$ dapat ditolak.

$$
\begin{aligned}
\mathrm{X}= & \alpha_{0}+\alpha_{1} \mathrm{Y}+\alpha_{2} \mathrm{Y}_{(-1)}+\alpha_{3} \mathrm{Y}_{(-2)}+\beta_{1} \mathrm{X}_{(-1)} \\
& +\beta_{2} \mathrm{X}_{(-2)}+\mathrm{U}_{1} \ldots \ldots \ldots \ldots \ldots \ldots \ldots \ldots \ldots \ldots . .(3) \\
\mathrm{X}= & \alpha_{0}+\beta_{1} \mathrm{X}_{(-1)}+\beta_{2} \mathrm{X}_{(-2)}+\mathrm{U}_{2} \ldots \ldots \ldots \ldots . .(4)
\end{aligned}
$$

Null hypothesis $\left(\mathrm{H}_{0}\right): \alpha_{1}=\alpha_{2}=0$

$\mathrm{X}$ menyebabkan $\mathrm{Y}$ jika $\mathrm{H}_{0}: \alpha_{1}=\alpha_{2}=0$ dapat ditolak.

Keputusan apakah ekspor riil mempengaruhi GDP atau sebaliknya GDP mempengaruhi ekspor riil digunakan uji F. Nilai F hitung diperoleh dari formula sbb:

$\mathrm{F}=(\mathrm{n}-\mathrm{k}) \frac{\left(R S S_{R}-R S S_{U R}\right)}{m\left(R S S_{U R}\right)}$ 
Dimana, $\mathrm{RSS}_{\mathrm{R}}$ dan $\mathrm{RSS}_{\mathrm{UR}}=$ berturutturut adalah nilai Residual Sum of Squares di dalam persamaan restricted dan unrestricted; $\mathrm{n}=$ jumlah observasi; $\mathrm{m}=$ jumlah lag; $\quad \mathrm{k}=$ jumlah parameter yang diestimasi di dalam persamaan unrestricted.

\section{PEMBAHASAN}

Uji kausalitas yang pertama yaitu antara Net Export Indonesia dan GDP Indonesia. Berdasarkan hasil uji kausalitas pada lag 2 diperoleh F-stat sebesar 0,11 untuk Net Export terhadap Gross domestic Product dan F-stat sebesar 0,79 untuk Gross Domestic Product terhadap Net Export, pada $\alpha=$ $10 \%$ dan $\mathrm{df}=27$ diperoleh F-tab sebesar 2,06. Hal ini dapat disimpulkan bahwa F-stat 2,40 > F-tab 2,06 berarti untuk variabel Net Export terhadap Gross Domestic Product menolak Ho, yang diartikan sebagai Net Export berpengaruh terhadap Gross Domestic Product. Untuk variabel Gross Domestic Product terhadap Net Export 0,23 < Ftab 2,06 berarti menerima Ho, yang diartikan sebagai Gross Domestic Product tidak mempengaruhi kenaikan atau penurunan Net Export . Dengan demikian terjadi hubungan satu arah antara Net Export terhadap Gross Domestic Product untuk Negara Indonesia.

Uji kausalitas yang kedua yaitu antara Net export China terhadap Gross Domestic Product China. Berdasarkan hasil uji kausalitas pada lag 2 diperoleh F-stat sebesar 0,02 untuk Net Export terhadap Gross Domestic Product dan Fstat sebesar 0,01 untuk Gross Domestic Product terhadap Net Export, pada $\alpha=$ $1 \%$ dan $\mathrm{df}=27$ diperoleh F-tab sebesar 3,75. Hal ini dapat disimpulkan bahwa F-stat 4,44 > F-tab 3,75 berarti untuk variabel Net Export terhadap Gross domestic Product menolak Ho, yang diartikan sebagai net Export mempengaruhi Gross Domestic Product. Untuk variable Gross Domestic Product terhadap Net Export F-stat 6,94 > F-tab 3,75 berarti menolak Ho, yang diartikan sebagai Gross Domestic Product mempengaruhi Net Export. Dengan demikian tejadi hubungan kausalitas antara Net export terhadap Gross Domestic Product untuk Negara China.

Secara teori, pertumbuhan net ekspor dan pertumbuhan ekonomi mempunyai hubungan timbal balik secara positif. Artinya jika pertumbuhan net ekspor naik maka pertumbuhan ekonomi juga naik dan jika pertumbuhan net ekspor turun maka pertumbuhan ekonomi juga akan turun. Demikian pula sebaliknya jika pertumbuhan ekonomi naik maka pertumbuhan net ekspor naik dan jika pertumbuhan ekonomi turun maka pertumbuhan net ekspor turun. Sedangkan berdasarkan uji kausalitas Granger di atas menunjukkan bahwa pada periode 1990 - 2009, di Indonesia dan China memperoleh hasil yang berbeda dimana di Indonesia diketahui bahwa pertumbuhan net ekspor mempengaruhi pertumbuhan ekonomi, sedangkan di China ada hubungan timbal balik atau hubungan positif antara net ekspor dan pertumbuhan ekonomi dalam hal ini nilai Gross Domestic Productnya, yang keduanya dapat saling mempengaruhi, kenaikan net ekspor dapat meningkatkan GDP atau pertumbuhan ekonomi, sebaliknya adanya kenaikan pertumbuhan ekonomi yang tinggi mampu mendorong kenaikan ekspor riilnya.

Hasil analisis tersebut sesuai dengan kondisi ekspor Indonesia yang dipengaruhi oleh kondisi global. Adanya goncangan luar negeri dapat berakibat pada menurunnya permintaan barangbarang ekspor domestik sehingga produksi menurun. Adanya penurunan produksi mengakibatkan para pekerja atau buruh mengurangi konsumsi dan 
investasinya sehingga pendapatan nasional juga menurun yang pada akhirnya menurunkan pertumbuhan ekonomi. Begitu pula sebaliknya, jika kondisi luar negeri mengalami perbaikan, ini akan berdampak pada kenaikan permintaan ekspor Indonesia sehingga produksinya akan meningkat dan para buruh dan pekerja pabrik lainnya juga mampu meningkatkan konsumsi dan investasinya yang berujung pada peningkatan pertumbuhan ekonomi. Alasan lainnya, karena pasar domestik di Indonesia sangat luas sehingga sebagian besar ekspor terserap di dalam negeri.

Barang-barang yang diekspor biasanya berupa barang-barang mentah yang berasal dari sektor pertanian, pertambangan, dan industri. Dalam jangka panjang, pertumbuhan ekonomi Indonesia akan terus melemah jika hanya bergantung pada ekspor tersebut karena pada dasarnya Indonesia hanya mengekspor sumber daya alam yang sulit untuk diperbaruhi yang pada akhirnya akan habis untuk kebutuhan domestik dan luar negeri (ekspor).

Sedangkan di China memiliki kondisi yang berlawanan dengan di Indonesia. Disamping pertumbuhan ekonomi mampu meningkatkan net ekspornya, ternyata net eksporpun memiliki kemampuan dalam meningkatkan pertumbuhan ekonominya yang diwakili oleh nilai GDP. China mempunyai komoditi ekspor yang dapat mempengaruhi permintaan dan penawaran luar negeri.

Ada beberapa pertimbangan yang membuat produk-produk China mampu bersaing di pasar global. Pertama, dalam kurun waktu 1998 2008, similarity index dari produk ekspor industri nasional dengan produk ekspor industri China bukannya menurun, tetapi justru meningkat dari 58,9\% (1996) menjadi hampir 62\% (2008). Ini berarti bahwa struktur perdagangan diantara kedua negara bersifat subsitusi daripada komplementer. Pemberlakuan ACFTA akan membuat produk industri nasional harus head to head bersaing dengan produk industri China.

Kedua, dengan menggunakan rasio output terhadap tenaga kerja sebagai proksi produktivitas, perhitungan menunjukkan bahwa gap produktivitas tenaga kerja Indonesia dengan produktivitas tenaga kerja China justru semakin melebar. Pada tahun 1996, produktivitas tenaga kerja Indonesia adalah $70,1 \%$ dari produktivitas tenaga kerja China, sedangkan pada tahun 2008 menurun menjadi hanya $65,4 \%$.

Ketiga, dibandingkan dengan Pemerintah Indonesia, Pemerintah China memiliki action plan cukup jelas untuk menata sektor industrinya. Misalnya, Pemerintah China menyediakan dana yang cukup besar untuk membantu industri andalan eskpornya, seperti industri TPT, untuk melakukan restrukturisasi permesinan. Tidak mengherankan bila permesinan yang digunakan industri China sangat efisien dengan produktivitas tinggi. Misalnya, permesinan yang digunakan industri TPT China mampu menghemat energi $17 \%$ lebih rendah dari permesinan yang digunakan industri TPT Indonesia.

Keempat, Pemerintah China memiliki komitmen yang sangat kuat untuk menciptakan lingkungan yang probisnis. Selain melakukan reformasi birokrasi, menegakan law enforcemen, dan mencipatakan stabilitas ekonomi makro, Pemerintah China mengalokasikan anggaran yang cukup signifikan untuk membangun dan menjaga kualitas infrastruktur. Dalam sepuluh tahun terakhir, budget infrastruktur sebagai rasio terhadap PDB China selalu berada dikisaran 7,5-10\%.

Berbeda dengan di China, dalam sepuluh tahun terakhir anggaran 
infrastruktur yang dialokasikan Pemerintah Indonesia relatif sangat kecil dan cenderung terus menurun dari $3.7 \%$ (1999), 3.6\% (2003), 2.9\% (2008), dan hanya $1.5 \% \quad$ (2009). Tidak mengherankan bila beberapa studi menyimpulkan bahwa infrastruktur menjadi salah satu kendala serius yang dihadapi sektor industri untuk memperbaiki dan meningkatkan daya saingnya. Misalnya, studi World Bank (2005) menunjukkan bahwa 900 perusahaan industri yang disurvey mengaku kehilangan $4 \%$ sampai $6 \%$ dari total penjualan mereka masing-masing karena jeleknya infrastruktur trasnportasi dan energi.

Kelima, beberapa BUMN yang menguasai industri hulu, seperti Pertamina dan PLN, tidak beroperasi secara efisien. BUMN itu mentransfer ketidakefisienannya kepada industri nasional dengan menetapkan harga jual yang tinggi bagi produk/jasa yang dihasilkannya kepada industri nasional.

Keenam, otoritas moneter di China mampu mendorong perbankan bekerja secara efisien sehingga mampu menyediakan kredit murah. Bunga kredit yang ditawarkan perbankan China ada di kisaran 5-6\%, jauh lebih rendah daripada bunga kredit yang ditawarkan perbankan Indonesia, yang masih berada di kisaran $13-14 \%$. Tingginya bunga kredit yang harus dihadapi perusahaan industri Indonesia menyebabkan mereka mengeluarkan biaya modal $8 \%$ lebih tinggi dari biaya modal yang harus di bayar perusahaan China.

Dari pembahasan diatas dapat kita ketahui upaya-upaya yang harus dilakukan oleh pemerintah untuk dapat meningkatkan pertumbuhan ekonominya. Tanpa adanya upaya yang serius untuk menata ulang industri nasional, maka dikhawatirkan bahwa industri nasional akan semakin terdegradasi didalam perekonomian nasional. Bukan tidak mungkin gejala awal deindustrialisasi (penurunan kontribusi sektor industri dalam menciptakan output dan menyediakan kesempatan kerja) akan semakin bertambah luas seiring dengan pemberlakuan ACFTA.

\section{PENUTUP}

Memasuki era globalisasi perdagangan internasional merupakan pintu untuk berhubungan dengan Negara lain di seluruh dunia. Hubungan ini bisa akan memberi dampak posistif pada suatu Negara manakala Negara tersebut mampu mangambil keuntungan dari adanya hubungan dagang ini. Salah satu cara untuk mengetahui bahwa perdagangan luar negeri dapat member dampak yang positif manakala net ekspor atau ekspor riil dapat menunjang kenaikan atau pertumbuhan ekonomi dengan meningkatkan GDP, sebaliknya adanya kenaikan GDP berdampak positif dalam menunjang ekspor riil.

Dari hasil penelitian ini didapat bahwa untuk Negara Indonesia adanya kenaikan net ekspor dapat memacu pertumbuhan ekonomi dengan kenaikan GDP, sedangkan GDP tidak berpengaruh terhadap kenaikan net ekspor atau ekspor riil. Hal ini mengindikasikan bahwa kondisi pasar dunia sangat berpengaruh terhadap permintaan barang domestic, adanya kenaikan permintaan pasar dunia terhadap produk domestic mampu meningkatkan pendapatan Negara dengan meningkatkan GDP, namun sayangnya kondisi ini tidak didukung dengan kinerja yang baik dari pemerintah dalam mendorong pertumbuhan sector riil, misalnya tersedianya infrastrukutur yang memadai, tersedianya anggaran dalam hal ini modal yang dapat membantu industry dengan restrukturisasi permesinan, kemudahan birokrasi, dan meningkatkan kinerja perbankan dalam 
mendukung produksi dengan memberikan kredit dengan bunga yang ringan sehingga biaya yang dikeluarkan sector riil dalam membiayai permodalan menjadi lebih ringan.

Sedangkan di China Negara tersebut telah dapat mengelola pertumbuhan ekonominya sehingga outputnya memiliki daya saing di pasar internasional.

\section{DAFTAR PUSTAKA}

Mankiw, N. Gregory. 2003. Teori Makro Ekonomi. Jakarta : Erlangga.

Perbongso, Aryo. 2009. Ancaman ACFTA. Online at http://edt31.org/opini29.htm. post november 2009.

Dornbush. 2004. Makro Ekonomi, Edisi kedelapan. Jakarta : PT. Media Global

Echwan. 2009. Indonesia vs China : Studi Komparatif Bisnis Ekonomi dalam ACFTA 2010. Online at http://nusantaranews.wordpress.co $\mathrm{m} / 2009 / 12 / 30$. post December, 30 2009

Nuryati, Yati, Deasy Natalia dan Nurozy. 2010. Tinjauan Umum: Hingga Agustus 2010. Tinjauan Terkini Perdagangan Indonesia vol 8, oktober $2010: 1-11$.

Depdag. $2010 . \quad$ Kementerian Perdagangan Republik Indonesia: ASEAN-CHINA. Online at http://www.depdag.go.id. Post November, 282010

Latif, Adam. 2010. ACFTA dalam Perspektif Hubungan dagang Indonesia China. Online at http://inspirasitabloid.wordpress.co m. Post March, 282010.

Basri, Faisal dan Haris Munandar. 2010. Dasar-dasar Ekonomi
Internasional. Jakarta : Kencana

Widarjono, Agus. 2005. Ekonometrika : Teori dan Aplikasi untuk Ekonomi dan Bisnis. Yogyakarta : Ekonisia Fakultas Ekonomi UII.

Murni, Asfia. 2006. Ekonomika Makro. Bandung : Refika Aditama.

Suparmoko, M. 1999. Metode Penelitian Praktis (Untuk Ilmu-ilmu Sosial, Ekonomi dan Bisnis), Edisi Keempat. Yogyakarta : BPFE

Simorangkir, Iskandar. 2007. Koordinasi kebijakan Moneter dan Fiskal di Indonesia : Suatu Kajian dengan Pendekatan game Theory, dalam Buletin ekonomi dan Moneter Vol. 9, N0. 3, Januari 2007

Warsono. 2008. Kontribusi Pasar Modal Terhadap Perekonomian Indonesia, dalam Media Manajemen dan Usahawan Indonesia. No. 04/TH. XXXVII 2008 
